Datokarama English Education Journal Vol. 2 No. 2, 2021

\title{
IMPROVING ENGLISH VOCABULARY MASTERY THROUGH TALKING STICK STRATEGY AT THE TENTH GRADE STUDENTS OF SMA NEGERI 1 KASIMBAR
}

WahyuFawsanAlansah

NurAsmawati

Ana Kuliahana

\author{
Study Program of English Tadris Faculty of Tarbiyah and Teacher Training \\ State Islamic University (UIN) Datokarama Palu \\ E-mail: wahyufauzan637@gmail.com
}

\begin{abstract}
Students usually feel bored in vocabulary lesson because they have less vocabulary and the teacher used same strategy in every meeting. In learning vocabulary, it is important used attractive strategy in order to the students interest to learn vocabulary. This research focuses on the using of talking stick strategy to the tenth grade students' vocabulary mastery at SMA Negeri 1 Kasimbar. The researcher applied quasi experimental research design and need pre-test and post-test to both experimental and control class. The pre-test was to know the level of students' vocabulary mastery ability before giving treatment while the post-test was used to know the result after giving treatment. There was a significant difference score of the post-test of the experimental class $(696,64)$ and the control class $(516,66)$. The level of significance was set up 0,05 with 18 degree of freedom $((\mathrm{df})=\mathrm{Nx}+\mathrm{Ny}-2=10+10-2)$. The result of data analysis indicates that tcounted $(2,573)$ which was higher than table $(2,153)$,it means that the hypothesis of the research was accepted. Thus, there was significant score improvement of using talking stick strategy to the tenth grade students at SMA Negeri 1 Kasimbar.
\end{abstract}

Keywords: Improving,Vocabulary, Talking Stick 


\section{Datokarama English Education Journal Vol. 2 No. 2, 2021}

\section{Background}

Vocabulary is one of important component in language. It is a key of communication. Without vocabulary, the communication cannot run well and effective. Studying language started by learning vocabulary first. So the basic in learning English is learn about vocabulary it because vocabulary determine how good people in communication.

Hornby stated vocabulary is a list of words with their meaning, response which accompanies a text book in foreign language". Moreover, according to "The Advance Learner's dictionary", "vocabulary is (range of words) know to, or used by a person profession". ${ }^{1}$ Richard also state vocabulary is a set of words. A vocabulary is as unique to a content area as fingerprints are to a human being. ${ }^{2}$ The definition suggests that in order to have a communication or perform a profession, we should have or know a range of words.

In teaching vocabulary to students, it is difficult to students to comprehend the lesson. It caused students did not serious in class because they have less vocabulary to interact to their teacher. Sometimes, the students want to answer teacher's questions but they do not have much vocabulary to communicate for that reason the students being passive in the classroom. Without vocabulary, it is hard to students to speak or write any materials in

\footnotetext{
${ }^{1}$ Hornby in Reza Apriliah, "Increasing students' vocabulary of $X$ grade at SMA Negeri 3 ToliToli through crossword puzzle"

${ }^{2}$ Richard in Reza Apriliah, "Increasing students' vocabulary of $X$ grade at SMA Negeri 3 ToliToli through crossword puzzle"
}

class and difficult to understand what their teacher talk to them.

On the other hand, teacher should offers variety of vocabulary materials. Teacher can uses different ways to present vocabulary including pictures, sounds, and different types of text such as stories, conversation, web pages, etc. The topics that will be presented should be relevant to students' interest and engage students with different level. ${ }^{3}$

Based on the researcher's observation at SMA Negeri 1 Kasimbar, the researcher found some problems. The students were lack of vocabulary because when the researcher observe English teacher at SMA Negeri 1 Kasimbar, the teacher said that the students low in vocabulary it is show based on the result of students score on vocabulary lesson. The students received less vocabulary from any meeting and the teacher used the same strategy on each meeting. Then, students got boring with some strategy that the teacher gave to them for that reason the students become lazy to learn about vocabulary. For that reason, it is important to find other effective strategy to improve students' vocabulary mastery in learning session.

Based on the issues above, the students should be given a new strategy that can accommodate their needs to improve vocabulary mastery in learning session. One of the strategies is talking stick strategy. Talking stick strategy is one of cooperative learning in the learning process by a stick, the students who get the stick must answer the question

${ }^{3}$ Bastian Sugandi, The impact of using English songs towards the students' vocabulary mastery at grade ten of SMK Negeri 1 Bandar Lampung in academic year 2013-2014, The Fourth International Conference on Education and Language (4th ICEL) 2016Universitas Bandar Lampung (UBL), Indonesia (2014) 


\section{Datokarama English Education Journal Vol. 2 No. 2, 2021}

from the teacher. Talking stick strategy is not only practice to the students to speak up but also creates fun and active condition in the class. $^{4}$

According to Knockwood, Talking Stick is a piece of wood used in Talking stick ceremony. Anyone with the talking stick would have the right to talk as long as they need to say without fear of being interrupted with question, criticism or scolding. In classroom, the talking stick can be any ordinary stick of any kind or size. Passing the Talking Stick is powerful method of creating deep communication between people. ${ }^{5}$

Talking stick strategy is a suitable strategy to teach in the school. The students feel happy and enjoy the strategy. The students become more active in doing the learning activities in classroom like answer the teacher's questions, listen to the materials, and speak each other with their friends. So, the students cannot feel boring in their leaning session. The teacher becomes more creative with using talking stick strategy in teaching vocabulary.

Based on the explanation above, the researcher interested to conduct the research at the tenth grade students of SMA Negeri 1 Kasimbar to improve students' vocabulary mastery.

${ }^{4}$ LilikNurbaidah, "Improving the students' speaking skills by using talking stick strategy among the eight graders od SMP N 4 Sekampung, East Lampung",

${ }^{5}$ Knockwood inHamdiahArif, "The Effectivenes of Talking stick Method in Teaching Vocabulary at the Second Grade of MTs Madani PaoPao"

\section{Literature Review}

\subsection{Vocabulary}

Vocabulary is a list of words and their combination in particular language. ${ }^{6}$ Vocabulary is one of important thing that people should be master when people learn about English. Vocabulary is basic skill to makes communication runs well. Good said that vocabulary is the words having meaning when heard or seen even though not produced by the individual himself or communicate with other. ${ }^{7}$ Then, vocabulary is the word that having meaning and it can use to communicate well to each other.

Chart stated that vocabulary are it all the word of language, then it all the words used or understand by particular person, class, profession, and a list of word and phrases especially one arrange in alphabetically order defined or translated lexicon glossary. ${ }^{8}$ Vocabulary plays important role in language as well especially for communication. Then, human can get knowledge based on vocabulary that they have and change to be the information.

Based on explanation above, the researcher concludes that vocabulary is very important in life. Vocabulary can constructs the words and change them to information to communicate, share an idea, etc. Vocabulary is a basic to learning English as well,it caused the language to have meaning. Vocabulary also helps to constructs a new sentence that

\footnotetext{
${ }^{6}$ Joklova : 2009 in Elsa Yuriska Sitompul . "Teaching Vocabulary Using Flashcards And Word List." (Jakarta, Universitas Indonesia, 2013)

${ }^{7}$ Reza Apriliah, "Increasing students' vocabulary of $X$ grade at SMA Negeri 3 ToliToli through crossword puzzle"

${ }^{8}$ Chart in HamdiahArif, "The Effectivenes of Talking stick Method in Teaching Vocabulary at the Second Grade of MTs Madani PaoPao"
} 


\section{Datokarama English Education Journal Vol. 2 No. 2, 2021}

everyone can understand. Then, it is too much important to improve vocabulary mastery to communicate effectively.

\section{a. Kinds of vocabulary}

According to Arguelle, vocabulary is divided into two kinds, receptive and expressive, both are: ${ }^{9}$

1) Receptive Vocabulary

Requires a reader or listener to associate a specific meaning with a given label as in reading or listening. It means that the students usually find receptive or passive vocabulary in listening or reading materials. They will be find the meaning of the word when they read the words in a text and will know the meaning of the unknown word on the text.

\section{2) Expressive Vocabulary}

Requires the writer to produce a specific label for a particular meaning. It means that vocabulary can be used by a language user commonly and there are no such difficulties in expressing it.

Based on the explanation above, receptive vocabulary and expressive vocabulary can be concludes that in vocabulary students sometimes difficult to get new vocabulary which caused they did not know about the unknown words of the material. Then, students can express the word because the students familiar to the world for that reason the students feel easy to get it. Familiar words can help the students to get a new vocabulary then the students will easily express the words.

\section{b.Types of vocabulary}

According to Fries, there are four types of vocabulary described as follow: ${ }^{10}$

1) Function words

The first type of vocabulary is "function words", although some of them may have full word meaning content, primarily or largely operate as means of expressing relations of grammatical structure.

2) Substitute words

The second type of vocabulary items consist of the "substitute" words, those words which represent not individual things or specific actions, but function as substitutes for whole form-classes of word.

3) Grammatical Matters as presence or absence of a negative

The third type of vocabulary item consist of those that are distributed in use according to such grammatical matters as the presence or absence of a negative, include; some-any, too either, already yet, still anymore, quite (exception).

4) Content Words

The lare body of "content" words constitutes the fourth group of vocabulary items and the chief material usually considered when the vocabulary of a language is discussed. These are the words that function as symbols for the phenomena which we react upon as the world of reality about us, symbol for "thing", for "action" and for "qualities".

Based on explanation above, there are four types of vocabulary there are function words, substitute words, grammatical matters, and content words. It can concludes that vocabulary have a meaning to share an information effectively. Then, students have to learn vocabulary mastery so they can learn English easily. The students also can master

10 Fries in Laila Monica Rohmawati, "Theeffectiveness of talking stick methodtoward the students'vocabulary masteryof eight gradein SMPN 2 Bantur Malang"
"Theeffectiveness of talking stick methodtoward the students'vocabulary masteryof eight gradein SMPN 2 Bantur Malang" 


\section{Datokarama English Education Journal Vol. 2 No. 2, 2021}

the four of languages skill easily by learning vocabulary.

\section{c. Principle of Teaching and Learning Vocabulary}

Wallace indicates the principles of teaching and learning vocabulary. There are: ${ }^{11}$

\section{1) Aims}

In teaching vocabulary, the teachers have to know the aims of words taught, why he/she teach vocabulary. So, he/she can select kinds of vocabulary that he/she should teach.

2) Quantity

In this part, the teacher has to decide the number of new words that the student has to know and be taught clearly. The actual number will depend on the number factor varying classes and students. And the teacher has to consider the number of vocabulary taught, because it can give an effect to the students in learning vocabulary. If there are too many words to be taught, the studentsbecame confused, discouraged, and frustrated.

3) Need

In this case, the teacher have to select the words that the teacher will teach to the students based on aims of the course and the objective of individual lesson's, students background and language need. In other words the teacher has to know who the students are.

4) Frequent, Exposure, and Repetition

In teaching and learning vocabulary, there has to be certain amount of repetition until there is an evidence that the students learn the target words.

5) Meaningful Presentation

In presenting vocabulary, the teacher has to give clear explanation, specific understanding of words detonated or refers to.

\footnotetext{
${ }^{11}$ Wallace in HamdiahArif, "The Effectivenes of Talking stick Method in Teaching Vocabulary at the Second Grade of MTs Madani PaoPao"
}

The representation of the words must be perfect, meaningful and unambiguous.

6) Situation

In explaining and teaching vocabulary, the teacher must know the situation and the atmosphere of the class whether the students are ready or not to accept the lesson, it will influence students acquire to the vocabulary.

7) Presenting in context

One way in teaching new or unfamiliar vocabulary is taught through reading material. It is very useful to the students in improve students vocabulary acquire and the words position in learning sentences.

8) By mother tongue and target language

In teaching words in target language, teacher can use the mother tongue as a tool in comparing the similarities and differences of the words.

9) Guessing procedure in vocabulary learning

Guessing is one way in teaching vocabulary, it will help the students the vocabulary that have taught before and it leads the students to think the meaning of the new words taught.

Based on the explanation above, there are many principle of teaching and learning vocabulary. It is use to help the student and the teachers in teaching and learning vocabulary. The principles of teaching and learning vocabulary makes the learning session more effective in classroom.

\section{d. The Technique of Learning Vocabulary}

According to Beare, there are many ways to improve our vocabulary. When working to improve your vocabulary it is important to know your goals in order to best choose the way in which you want to learn. ${ }^{12}$

${ }^{12}$ Beare in HamdiahArif, "The Effectivenes of Talking stick Method in Teaching Vocabulary at the Second Grade of MTs Madani PaoPao 


\section{Datokarama English Education Journal Vol. 2 No. 2, 2021}

Based on explanation above, in

1) Vocabulary trees

Vocabulary trees help provide context, once you have out of a few vocabulary trees, you will discover yourself thinking in vocabulary groups. When you see a cup your mind will quickly relate such words as knife, late, dishes, and etc.

2) Create vocabulary themes

Create list of vocabulary themes; include the vocabulary, definition and example sentence for each new item.

3) Use technology

Technology help you understand native speakers of English. Using the fancy options watching individual scenes can help make DVD use into a vocabulary learning exercise.

4) Specific vocabulary lists

Rather than studying a long list of unrelated vocabulary, use specific vocabulary lists to help you prepare for type of vocabulary we need for work, specific vocabulary items.

5) Word formations chart

Word formations are one of the keys to success for advanced level ESL (English Second Language) learners. Advanced level English exams such as the TOEFL and proficiency use word formation as one of the key testing elements, these word formation charts provide the concept noun, personal noun, adjective and verb forms of key vocabulary listed in alphabetical order.

6) Visual dictionaries

A picture is worth a thousand words. It is also very helpful for learning precise vocabulary. There are a number of excellent English learner visual dictionaries for sale.

7) Use a corpus

Corpora are huge collections of documents that can tract the number of times a word is used. By using corpora, you can find which words are often uses together with target vocabulary words. Combining corpora use with vocabulary. teaching vocabulary the teachers should know what kinds of technique to use in teaching vocabulary based on students needed. It means, every student has their own difficulties to learn vocabulary and the teachers should find out the problems of the students in learning vocabulary mastery within use technique in teaching vocabulary. Then, the students can get vocabulary as well based on the difficulties that they have. Finally, learning vocabulary mastery more effective to students it caused students feel comfortable with technique that teacher has given.

\section{e. The importance of vocabulary}

Vocabulary knowledge is often viewed as a critical tool for second language learners because a limited vocabulary in a second language impedes successful communication. Underscoring the importance of vocabulary acquisition, Richard and Willy stated that Vocabulary is a core component of language proficiency and provides much of the basis for how well learners speak, listen, read, and write. Without an extensive vocabulary and strategies for acquiring new vocabulary, students often achieve less than their potential and may be discouraged from making use of language learning opportunities around them such as listening to the radio, listening to native speakers, using the language in different context, reading, or watching television. ${ }^{13}$

Bromley states that vocabulary holds some important roles in teaching learning process. They are: ${ }^{14}$

\footnotetext{
${ }^{13}$ Richard and Willy in Laila Monica Rohmawati,"Theeffectiveness of talking stick methodtoward the students'vocabulary masteryof eight gradein SMPN 2 Bantur Malang”

${ }^{14}$ Bromley in Laila Monica Rohmawati,"Theeffectiveness of talking stick methodtoward the students'vocabulary masteryof eight gradein SMPN 2 Bantur Malang”
} 


\section{Datokarama English Education Journal Vol. 2 No. 2, 2021}

1) Promoting fluency

Students who recognize and understand many words read more quickly and easily than those with smaller vocabularies.

2) Boosting comprehension

Vocabulary knowledge strongly influences comprehension. On a component analysis of comprehension, word meanings were found to make up $74 \%$ of comprehension.

3) Improving achievement

A large vocabulary means a large of conceptual knowledge which makes academic learning easier. Students with large vocabulary score higher on achievement test then those with small vocabularies.

4) Enhancing thinking and communication

Words are tools for analyzing, inferring, evaluating and reasoning. A large vocabulary allows for communicating in ways that are precise, powerful, persuasive and interesting.

Based on the importance of vocabulary above, it concludes that the students can increase their skill in learning language as well. It is show that with learning vocabulary students can improve their fluency in language as well. Then, learning vocabulary can boost the students' vocabulary mastery.

Vocabulary also can enhance the students' communication as well. Furthermore, the effectiveness in learning vocabulary mastery through using talking stick can be measure based on how students master large vocabulary. It is cause, the importance to learn vocabulary can improve students' achievement if the students can master a large number of vocabulary have high score than student that master less vocabulary.

\subsection{Talking stick}

According to Laura Candler, Talking Stick is a strategy that encourages all the students to participate equally in the learning. The student who gets the stick must answer the question from the teacher or follow the teacher's instruction. ${ }^{15}$

The students who get the stick must answer the question by the teacher after read topic. This strategy can makes the students interested to participate in classroom and they can be more active in learning session.

Talking Stick (spoken stick) has been used for centuries by Indian tribes as a means of listening to fairly and impartially. Talking stick often used the council to decide who has the right to speak. By the time chairman of the meeting began to discuss and discuss the issue, he must hold a stick. Stick will move to others if he wants to speak or respond. In this way the talking Stick will move from one person to another if the person wants to express his opinion. When all of the audiences turn to speak then it returned again to the chairman of the meeting. ${ }^{16}$

\section{a. Procedure of talking stick}

Hartina stated that there are some steps implementations of talking stick by, which are: ${ }^{17}$

${ }^{15}$ Laura Candler in M.FuadZamzami, "The effectiveness Using Talking Stick Towards Students Vocabulary Mastery As Fifth Grade At MI AbunNajaWonodadi in Academic Year 2016/2017"

${ }^{16}$ Laila Monica Rohmawati ,"Theeffectiveness of talking stick methodtoward the students'vocabulary masteryof eight gradein SMPN 2 Bantur Malang”

${ }^{17}$ Hartinain HamdiahArif, "The Effectivenes of Talking stick Method in Teaching Vocabulary at the Second Grade of MTs Madani PaoPao" 


\section{Datokarama English Education Journal Vol. 2 No. 2, 2021}

1) Start the session by placing the talking stick on the floor with everyone sitting on chairs in a circle around it.

2) Trainer explains the rules and everyone agrees to abide by them. Nobody who rejects the rules can take part.

3) Give someone the role of timekeeper.

4) If using topic or issue based material present it now.

5) Begin with one person holding the talking stick. When they are holding the stick, they can talk for the agreed amount of time.

6) When the talker has stopped, they pass the talking stick to somebody else.

7) The next person holding the stick repeats the same process.

8) Continue the session until nobody else has anything left to say, which is signaled by a noticeable period when nobody is passed the stick.

b. The strength and weakness of talking stick

Every strategy has the strengths and weakness belong to the talking stick strategy. Aini defined that the talking stick method has strengths and weakness. This method gives the strength to attract the students' preparation, so they are more serious in learning English. However, talking stick method trains the students' to comprehend and recall the materials vividly. ${ }^{18}$

There are some weaknesses when applying this method, there are : Talking stick can make the students' strained and afraid therefore Students stress when they gets the stick and must answers the teacher's question.

According to Anita, talking stick also have some strengths in teaching implementation, they are: ${ }^{19}$

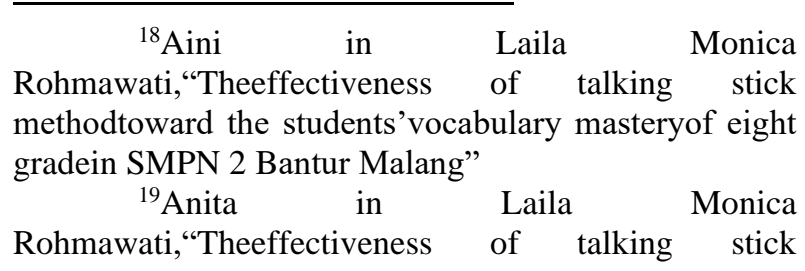

1) To test the readiness of the student in teaching learning process

2) Train the student to understand the material quickly

3) To gain the student bold confront their idea

4) To increase the student willingness to use other peoples' ideas are perceived better.

\section{Methodology}

In this research, the researcher used quantitative research to find out data and result of test. Then, look the differences before and after giving the treatment to the students. The researcher also look the improved of students' vocabulary in experimental class after giving the treatment.

The design of this research used quasiexperiment. This design was exactly like pretest post-test control group design except that there is no random assignment into group, Sugiono. A group of subject who receive a treatment, experimental group, is compare to control group who does not receive a treatment. ${ }^{20}$ In conducted this research, two classes of the tenth grade students involved. The first class been an experimental class and the second class been a control class. The experimental class used talking stick strategy and the control class did not used talking stick strategy.

The design of this research used the method: ${ }^{21}$

$\mathrm{O}_{1} \mathrm{X} \mathrm{O}_{2}$

methodtoward the students'vocabulary masteryof eight gradein SMPN 2 Bantur Malang”

${ }^{20}$ Sugiono in HamdiahArif, "The Effectivenes of Talking stick Method in Teaching Vocabulary at the Second Grade of MTs Madani PaoPao”

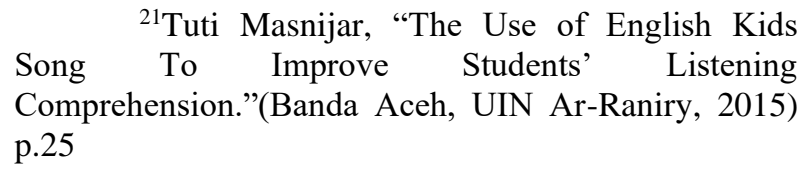


Datokarama English Education Journal Vol. 2 No. 2, 2021

$\mathrm{O}_{3} \quad \mathrm{O}_{4}$

Note:

$\begin{array}{ll}\mathrm{O}_{1} & \text { : pretest of experimental class } \\ \mathrm{O}_{2} & \text { : posttest of experimental class } \\ \mathrm{O}_{3} & \text { : pretest of control class } \\ \mathrm{O}_{4} & \text { : posttest of control class } \\ \mathrm{X} & \text { : treatment of experimental } \\ & \text { Class } \\ & \text { : there is no random of subject }\end{array}$

\section{Result and Discussion}

This research was conducted in the middle of the Corona pandemic, such as the time allocation of learning in the previous was $2 \times 45$ minutes when the researcher conducted the research.

In the first meeting of research, the researcher gave the pre-test to the students. In the pre-test, there were no students either in the controlled class or the experimental class who passed the minimum of standard achievement KKM (70).

The researcher applied the treatment ( talking stick strategy) at the second meeting until the seventh meeting. In the last meeting, the researcher gave the pre-test to the students. So, there were eight times of meeting's total for each class.

In the last meeting, the researcher gave the post-test to the students. It aimed to measure the students' vocabulary mastery after given the treatment. Based on the result of their post-test, it showed that in the controlled class, there were 3 students out of 10 who can pass the minimum of standard achievement 70 (KKM), while in the experimental class there were 6 students out of 10 who success to passed the KKM. It is clearly stated based on the result of t-counted that shows 2,573 that higher than t-table 2,153 . It shows that the use of the talking stick strategy can improve the students' vocabulary mastery at the tenth grade of SMA Negeri Kasimbar.

\section{Conclusion and Suggestions}

\subsection{Conclusion}

Based on the result of the research, the researcher concludes that before and after giving talking stick strategy there is any significant score improvement in vocabulary mastery at the tenth grade students at SMA Negeri 1 Kasimbar. It can be shown from the result of the t-counted was 2.573 , while the $\mathrm{t}-$ table was 2.153 lower than the t-counted. Therefore, the alternative hypothesis was accepted and the null hypothesis was rejected. Talking stick strategy can improve students vocabulary mastery at the tenth grade students of SMA Negeri Kasimbar.

\subsection{Suggestion}

In favor of increase the English teaching quality, the researcher would like to give so suggestions as follows:

1) The students should learn more about English vocabulary, particularly in the use of talking stick strategy.

2) Teachers should improve their method in the learning process of the class such as using talking stick strategy.

3) Further researchers who get the same research should use this research as the guidance to develop their research. . 


\section{Datokarama English Education Journal Vol. 2 No. 2, 2021}

\section{References}

Aini in Laila Monica Rohmawati, "The effectiveness of talking stick methodtoward the students'vocabulary masteryof eight gradein SMPN 2 Bantur Malang"

Anita in Laila Monica Rohmawati, "Theeffectiveness of talking stick methodtoward the students'vocabulary masteryof eight gradein SMPN 2 Bantur Malang"

Apriliah, Reza. "Increasing students' vocabulary of X grade at SMA Negeri 3 ToliToli through crossword puzzle"

Arguelle in Laila Monica Rohmawati, "The effectiveness of talking stick methodtoward the students'vocabulary masteryof eight gradein SMPN 2 Bantur Malang"

Beare in Hamdiah Arif, "The Effectivenes of Talking stick Method in Teaching Vocabulary at the Second Grade of MTs Madani PaoPao"

Bromley in Laila Monica Rohmawati,"The effectiveness of talking stick methodtoward the students'vocabulary masteryof eight gradein SMPN 2 Bantur Malang"

Chart in Hamdiah Arif, "The Effectivenes of Talking stick Method in Teaching Vocabulary at the Second Grade of MTs Madani PaoPao"

Fries in Laila Monica Rohmawati, "Theeffectiveness of talking stick methodtoward the students'vocabulary masteryof eight gradein SMPN 2 Bantur Malang"
Hartina in Hamdiah Arif, "The Effectivenes of Talking stick Method in Teaching Vocabulary at the Second Grade of MTs Madani PaoPao"

Hornby in Reza Apriliah, "Increasing students' vocabulary of $\mathrm{X}$ grade at SMA Negeri 3 ToliToli through crossword puzzle"

Joklova : 2009 in Elsa Yuriska Sitompul . "Teaching Vocabulary Using Flashcards And Word List." (Jakarta, Universitas Indonesia, 2013)

Knockwood in Hamdiah Arif, "The Effectivenes of Talking stick Method in Teaching Vocabulary at the Second Grade of MTs Madani PaoPao"

Laura Candler in M. Fuad Zamzami, "The effectiveness Using Talking Stick Towards Students Vocabulary Mastery As Fifth Grade At MI Abun Naja Wonodadi in Academic Year 2016/2017"

Masnijar,Tuti. "The Use of English Kids Song To Improve Students' Listening Comprehension.'(Banda Aceh, UIN Ar-Raniry, 2015) p.25

Nurbaidah,Lilik. "Improving the students' speaking skills by using talking stick strategy among the eight graders od SMP N 4 Sekampung, East Lampung”

Richard and Willy in Laila Monica Rohmawati,"The effectiveness of talking stick methodtoward the students'vocabulary masteryof eight gradein SMPN 2 Bantur Malang" 
Datokarama English Education Journal Vol. 2 No. 2, 2021

Richard in Reza Apriliah, "Increasing students' vocabulary of $\mathrm{X}$ grade at SMA Negeri 3 ToliToli through crossword puzzle"

Rohmawati, Laila Monica."The effectiveness of talking stick method toward the students' vocabulary masteryof eight gradein SMPN 2 Bantur Malang”

Sugandi, Bastian. The impact of using English songs towards the students' vocabulary mastery at grade ten of SMK Negeri 1 Bandar Lampung in academic year 2013-2014, The Fourth International Conference on Education and Language (4th ICEL) 2016Universitas Bandar Lampung (UBL), Indonesia (2014)

Sugiono in HamdiahArif, "The Effectivenes of Talking stick Method in Teaching Vocabulary at the Second Grade of MTs Madani PaoPao"

Wallace in Hamdiah Arif, "The Effectivenes of Talking stick Method in Teaching Vocabulary at the Second Grade of MTs Madani PaoPao" 